Indonesian Journal of Legality of Law
e-ISSN : 2477-197X
https://postgraduate.universitasbosowa.ac.id/

\title{
EFEKTIVITAS PEMBAGIAN HARTA BERSAMA TERHADAP PERCERAIAN DI PENGADILAN AGAMA SUNGGUMINASA KELAS IB
}

\author{
The Effectiveness Of Collective Assets Sharing On Divorce In The Class Ib Sungguminasa Religion Court
}

\author{
Nurbaya $^{1}$, Muh. Arfah Pattenreng ${ }^{2}$, Yulia A. Hasan ${ }^{2}$ \\ ${ }^{1}$ Kementerian Agarma, Kota Palu \\ ${ }^{2}$ Program Studi Ilmu Hukum Program Pascasarjana Universitas Bosowa \\ Email: nurbaya@gmail.com
}

Diterima: 10 September 2021/Disetujui: 01 Desember 2021

\begin{abstract}
ABSTRAK
Tujuan penelitian adalah untuk mengkaji efektivitas pembagian harta bersama terhadap perceraian di pengadilan agama sungguminasa kelas IB. Jenis penelitian hukum normative. Jenis data sekunder yaitu Putusan Pengadilan Agama Kabupaten Gowa Nomor 79/Pdt.G/2017/Pa.Sgm. Teknik pengumpulan bahan hukum Studi Kepustakaan. Analisis data kualitatif. Hasil penelitian menunjukkan efektivitas pembagian harta Bersama berasarkan putusan nomor 79/PDT.G/2017/PA. SGM telah efektif yang ditunjau berdasar kedudukan Hukum (legal standing) yang diperoleh penggugat serta partisipasi Pemerintah dan Aparat dalam membantu penggugat mendapatkan haknya efektif karena telah memenuhi mekanisme hukum yang ada. Adapun faktor-faktor yang mempengaruhi efektivitas pembagian harta bersama terhadap perceraian pada putusan nomor 79/PDT.G/2017/PA. SGM meliputi pada factor sosiologi yaitu penetapan putusan dan adanya pendukung seperti fasilitas. Sedangkan factor psikologi meliputi pada ketidakadilan ini sangat berkaitan dengan pola padang suami selaku penanggungjawab keluarga terhadap istri selaku ibu rumah tangga serta pengaruh budaya dan ideologi yang menjadi pertimbangan dalam memberikan hak seorang istri.
\end{abstract}

Kata Kunci: Efektivitas Hukum, Harta Bersama, Perceraian

\begin{abstract}
The aim of the study was to examine the effectiveness of the sharing of joint assets on divorce in the class IB sungguminasa religion court. This study is normative legal research. The type of secondary data is the Decision of the Religion Court of Gowa Regency Number 79 / PDT. G / 2017 / Pa. Sgm. The technique of collecting legal materials used in this research is Library Research. The data analysis used is qualitative analysis. The results showed the effectiveness of sharing joint assets based on decision number 79 / PDT.G / 2017 / PA. SGM has been effective based on the legal standing obtained by the plaintiff and the participation of the Government and the Apparatus in helping the plaintiff get his / her rights effectively because it has fulfilled the existing legal mechanisms. The factors that affect the effectiveness of the sharing of joint assets include sociological factors, namely the decision making and the existence of supporters such as facilities. While the psychological factor covering this injustice is closely related to the perspective of the husband as the head of the family and the wife as a housewife, as well as the influence of culture and ideology that are considered in giving the rights of a wife.
\end{abstract}

Keywords: Effectiveness, Joint Assets, Divorce

This work is licensed under Creative Commons Attribution License 4.0 CC-BY International license

\section{PENDAHULUAN}

Putusan Pengadilan Agama Kabupaten Gowa Nomor 79/Pdt.G/2017/Pa.Sgm, yang seharusnya terjadi adalah harta bersama yang disebut pada point 2. I, 2.II dan 2.III di atas dibagi menurut ketentuan hukum yang berlaku yaitu masingmasing pihak, baik Penggugat maupun Tergugat berhak atas $1 / 2$ (seperdua) bagian dari setiap obyek sengketa baik secara fisik atau berdasarkan nilai penjualannya secara lelang. Namun kenyataan dilapangan berbeda dengan ketentuan dalam Putusan Pengadilan Agama Kabupaten Gowa Nomor
79/Pdt.G/2017/Pa.Sgm, dimana penggugat (istri) telah berusaha untuk meminta hak-haknya atas keseluruhan obyek sengketa, namun Tergugat (suami) bersikeras tidak mau membaginya bahkan Tergugat (suami) selalu mengusir pergi Penggugat (istri) secara paksa dari tanah obyek sengketa I yang ditempatinya saat ini bahkan Tergugat (suami) melakukan tindakan penganiayaan baik fisik maupun psikis terhadap Penggugat (istri) agar meninggalkan tanah obyek sengketa I, namun hingga saat ini Penggugat masih tetap bertahan untuk tidak pergi dari tanah obyek sengketa I, sementara tanah obyek sengketa II dan III telah disewakan 
oleh Tergugat kepada pihak lain dan hasil sewanya tidak dibagikan kepada Penggugat.

Problematika yang terjadi pada pelanggaran putusan pengadilan tersebut menjadi acuan terkait efektivitas putusan dalam pembagian harta Bersama. Dimana sangat jelas dalam putusan bahwa harta Bersama yang terjadi setelah perceraian adalah $1 / 2$ (seperdua) bagian dari setiap obyek sengketa baik secara fisik atau berdasarkan nilai penjualannya secara lelang, namun hal tersebut meskipun telah ditegaskan dalam putusan, masih menjadi problematika dimana pihak yang menguasai harta Bersama tidak memunjukkanitikad baik untuk memberikan hak kepada mantan pasangannyaBerbagai upaya dilakukan pihak penggugat dalam mempertahankan harta bersama agar tidak membagi kepada mantan istri. Padahal telah jelas pengaturannya, di tunjukkan dalam pasal 97 yang memuat terkait ketentuan Kompilasi Hukum Islam dimana menjelaskan bahwa seseorang perempuan yang berstatus janda atau pun seorang laki-laki yang berstatus duda dan melakukan perceraian maka keduanya berhak mendapatkan harta bersama dengan besaran bagian $1 / 2$ (seperdua) dari harta milik bersama yang telah didapatkan dalam pernikahan dengan syarat, ketika tidak terdapat perjanjian yang terkait harta milik bersama sebelum pernikahan (Samin, 2016).

Maka menurut penulis ketidaktaatan salah seorang yang merupakan pihak pada putusan (Tergugat) yang telah ditetapkan menjadi salah satu factor yang mempengaruhi kefefktivan putusan tersebut. Seperti yang di kemukakan oleh Achmad Ali bahwa kesadaran terhadap hukum, kepatuhan pada hukum serta efektivitas terhadap perundang-undangan merupakan tiga aspek yang saling berkaitan satu sama lain. Seiring dengan adanya percampuran akan perihal kesadaran terhadap hukum yang disertai pada kepatuhan pada hukum tersebut, yang dimana keduanya merupakan perihal yang memiliki hubungan yang sangat era antara satu sama lain, akan tetapi merupakan hal yang mengandung makna berbeda. Kedua aspek tersebut merupakan factor penentu yang mempengaruhi akan keterlaksanaan perundang-undangan yang diterapkan di masyarakat (Achmad Ali, 2015).

Karena itu untuk mengukur efektivitas dalam kajian hukum merupakan hal yang tidak sesederhana kita piirkan, dimana suatu efektivitas jika dikaji berdasarkan beberapa paradigam serta bergantung siapa yang memberikan penilaian dan tentunya siapa yang menerapkannya. Bila dikaji pada sudut pandang secara ekonomi terkait produktivitas, maka manajer akan menunjukkan suatu pemahaman yang mengartikan bahwa suatu efektivitas harus memiliki kualitas dan kuantitas pada suatu produk dan jasa yang dihasilkan. Selanjutnya tingkat efektivitas dapat dinilai berdasarkan pada hasil perbandingan suatu perencanaan yang ditetapkan berdasarkan pada hasil yang diperoleh secara nyata. Sehingga jika suatu usaha yang dilakukan dan memperoleh hasil yang tidak sesuai perencanaan awal, maka perihal itu dikatakan tidak efektif (Soerjono Soekanto dan Abdullah Mustafa, 2015).

Hukum adalah merupakan suatu aturan yang dimuat didalam karya manusia yang berisikan tentang norma terkait pedoman tingkah laku dan larangandan juga terkait pada etika. Begitu pulah Hukum adalah cerminan dari keinginan manusia yang senantiasa menginginkan suatu kondis teratur dan melalui hukum tersebut, maka masyarakat dapat dibina dan diberikan arahan tentang ketaatan dan kepatuhan terhadap norma dan etika yang terdapat dalam hukum tersebut
(Soerjono Soekanto, 2015). Selain itu suatu hukum yang juga mengandung ide-ide yang telah dipilih oleh beberapa masyarakat yang telah disesuaikan dengan tempat dimana hukum tersebut dibuat dan dituangkan dalam suatu bentuk aturan yang selanjutnya, inilah yangakan menciptakan keadilan di tempat tersebut (Sri Hariati \& Musakir Salat, 2015).

Sedangkan efektivitas menurut kajian sosiologi hukum seperti yang dijelaskan Walgito (2015) dalam pendekatan secara sosiologis terkait suatu keterkaitan antara hukum dan etika disersertai logika dalam badan hukum tersebut. Fokus utama dalam pendekatan secara sosiologis yang dikemukakn oleh Gerald Turke (Ahmadi, 2015) disajikan berikut ini:

1) Pengaruh hukum kepada perilaku sosial.

2) Kepercayaan yang dimiliki masyarakat.

3) Organisasi sosial dalam perkembangan masyarakat dalam pranata hukum.

4) Tentang bagaimana hukum dibuat.

5) Mengenai situasi sosial yang menimbulkan suatu hukum.

Adanya pengajuan gugatan terhadap putusan harta bersama disebabkan adanya pihak merasa tidak puas terhadap putusan pengadilan karena merasa tidak terpenuhinya keutuhan dan kepastian hukum yang selanjutnya memberikan kerugian kepadanya. Hal ini termasuk pada teori interaksionisme simbolis lahir disebabkan akan kebutuhan secara continue dari manusia yang mengharapkan suatu solusi dari permasalahan yang terdapat di masyarakat dan sebaliknya. Dimana jawaban akan masalah yang ada dapat memberikan pengaruh terhadap individu dan selanjutnya membentuk suatu pertahanan serta dapat pula mengubah suatu pola hubungan dalam masyarakat (Hazairin, 2015). Jadi, teori interaksionisme simbolis merupakan suatu usaha yang menjelaskan fenomena sosial hukum secara lebih mikro serta secara kongkret terkait interelasi dan fungsional yang terjadi antara individu di dalam suatu komunitas di masyarakat. Ketika kita menggunakan teori interaksionisme simbolis sebagai suatu alat analisis terhadap disiplin hukum seperti suatu ketika seseorang mempertanyakan terkait jika dilakukan pelanggaran terhadap hukum, maka apakah individu yang melakukan pelanggaran akan terpengaruh besar terhadap pelanggaran yang dilakukan, ataukah hanya akn memberikan pengaruh sebatas pada aspek toleransi saja ataukah justru yang terjadi yaitu pengabaian yang dilakukan masyarakat terhadap pelanggaran tersebut dimana individu ini berada. Hal tersebut tentu benar adanya jika kedua aspek tersebut yakni masyarakat yang lain mempengaruhi satu sama lain secara positif dengan saling memberikan teguran terhadap pelanggaran tersebut maka akan tercipta suatu pelanggaran hukum dan perbaikannya (Mahadi, 2015).

Sudikno Mertokusumo menjelaskan terkait jika suatu kepastian hukum sebagai suatu jaminan jika hukum tersebut dijalankan yang kemudian menurut hukum individu yang memilik hak akan mendapatkan haknya sehingga putusan dapat ditetapkan. Meskipun suatu kepastian hukum sangat berkaitan erat dengan suatu keadilan, namun hukum tersebut tidak identi dengan suatu keadilan. Hukum tersebut memiliki sifat umum yang mengikat setiap individu dan merata, sedangkan yang dimaksud dengan keadilan merupahan hal yang memiliki sifat subjektif, individualistis, serta sifatnya tidak merata. Kepastian yang terdapat dalam hukum adalah penyelengaraan hukum yang dimana sesuai dengan isi hukum 
tersebut sehingga masyarakat memiliki kepastian hukum tersebut dapat dilaksanakan (Sukdikno Mertokusumo, 2016).

Otoritas seorang hakim agar dapat melakukan tersebut, telah dijelaskan dan ditentukan dalam pasal 16 ayat satu pada Undang-Undang Nomor 48/2009. Pada pasal tersebut terdapat penjelasan terkait Kekuasaan Kehakiman dimana dijelaskan, suatu kebebasan dalam menyelenggarakan otoritas seorang hakim secara yudisial tersebut bersifat tidak mutlak disebakan kewenangan seorang hakim merupakan penegakan hukum serta keadilan yang didasarkan pada Pancasila, dengan demikian putusan seorang hakim akan mencerminkan rasa keadilan rakyat Indonesia (Wijayanti, 2015).

\section{METODE}

Jenis penelitian hukum normatif dengan pendekatan yuridi dan teologi normatif. Sumber data yang digunakan Putusan nomor 79/PDT.G/2017/PA. SGM dan aturan-aturan terkait permbagian harta bersama setelah perceraian. Penelitian ini dilakukan di Kantor Pengadilan Agama Sungguminasa Kelas 1B. Teknik pengumpulan data adalah metode kepustakaan dimana putusan sebagai instrumen penelitian. Teknik analisis data deskripti f kualitatif.

\section{HASIL DAN PEMBAHASAN}

\subsection{Efektivitas Pembagian Harta Bersama Terhadap Perceraian pada Putusan nomor 79/PDT.G/2017/PA.SGM.}

Hukum seringkali tidak dapat secara efektif dalam mengatur hubungan yang terjadi antar manusia yang merupakan anggota masyarakat,biasanya disebabkan oleh adanya faktor-faktor manusia dalam kapasitasnya sebagai masyarakat maupun manusia sebagai pelaku hukum, perencana, pelaksana, penegak maupun pengaman hukum yang tidak mendukung keberlakuan suatu hukum yang dalam hal ini efektivitas pembagian harta bersama. Untuk melihat efektivitasnya maka terlebih dahulu, di tinjau dari dua hal yaitu legal standing dan peran aparat serta pemerintah dalam penerapannya secara efektif.

a. Legal standing

Legal standing dalam penerapan efektivtias hukum terhadap putusan nomor 79/PDT.G/2017/PA.SGM tentang harta bersama yang menunjukkan dimana seorang penggugat diberikan legal standing untuk mengajukan gugatan terhadap tergugat karena:

1. Penggugat adalah orang yang mengajukan gugatan karena mempunyai kepentingan hukum. . Penggugat dalam hal ini, seorang perempuan yang tidak mendapatkan haknya disebabkan ketidaktaatan hukum terhadap putusan pengadilan terkait harta milik bersama yang telah diputuskan terulur-ulur dikarenakan perlawanan hukum yang di lakukan pihak tergugat yang merupakan mantan suami penggugat yang secara nyatanyata enggan memberikan bagian yang menjadi hak mantan istri. Hal tersebut selanjutnya menunjukkan bahwa penggugat adalah orang yang dirugikan oleh berlakunya undang-undang yang secara konstitusi masing-masing warga negara memiliki hak asasi untuk mengajukan banding, Kasasi, dan Peninjauan kembali jika merasa tidak puas terhadap putusan.. Hal tersebut sudah tepat, dimana hukum secara adil memberikan hak yang sama kepada penggugat maupun tergugat.

2. Penggugat mempunyai kerugian bersifat khusus yang potensialnya dapat dihitung. Kerugian yang dialami oleh pihak pengugat karena upaya hukum yang ditempuh pihak tergugat meliputi pada kerugian finansial dan juga secara spikis. Dimana penggugat tidak mendapatkan haknya sebagaimana yang tertera dalam putusan. Panjangnya waktu untuk mendapatkan hak penggugat sehingga secara finansial harta bersama yang sdah seharusnya dapat dikelola dan memberikan hasil harus tertunda. Selain itu untuk kerugian secara spikis disebabkan kepastian hukum yang tidak jelas terkait kapan penggugat dapat menerima haknya yang terhitung sudah sejak 2017 mengajukan gugatan, namun baru terkabul setelah 2019.

3. Penggugat mempunyai hubungan sebab-akibat (causal verband). Adanya hubungan sebab akibat membuat penggugat memiliki legal standingyakni perceraian sehingga terjadilah perkara pembagian harta bersama dan perceraia tersebut menimbulkan konflik antara mereka. Dimana pihak tergugat tidak mau memberikan apa yang menjadi hak dari penggugat, sehingga menyebabkan penggugat mengajukan tuntutan atas haknya kepada tergugat.

4. Penggugat mempunyai peluang dan harapan .. Bahwa dengan adanya gugatan Penggugat maka Penggugat mempunyai peluang dan harapan bahwa akan ada haknya.Dan kerugian penggugat dalam hal ini disebabkan karena adanya itikad tidak baik tergugat dalam memenuhi putusan nomor 79/PDT.G/2017/PA. SGM untuk membagi harta milik Bersama $1 / 2$ bagian untuk masing-masing penggugat dan tergugat.

b. Peran aparat serta pemerintah

Substansi Hukum pada putusan Pengadilan Agama Sungguminasa dengan Nomor 79/Pdt.G/2017/PA.Sgm telah memenuhi persyaratan. Dimana putusan Pengadilan Agama Sungguminasa dengan Nomor 79/Pdt.G/2017/PA.Sgm yang telah ditempuh penggugat sampai pada tahap keluarnya surat perintah eksekusi harta bersama yang menjadi hak tergugat telah dilakukan. Peran dari aparat pemerintah setempat dalam membantu dan melindungi seseorang yang tidak mendapatkan haknya adalah pada proses eksekusi harta milik bersama dilakukan. Dimana pihak apparat yang terkait yaitu pengadilan, polisi sebagai pengamana dan lurah sebagai pemerintah setempat yang berkoordinasi sebagaimana mekanisme pelaksanaan eksekusi harta bersama telah efektif dan mereka patuhi. Akan tetapi pelaksanaan eksekusi dapat dilakukan setelah 2 tahun lebih tergugat mengulur waktu karena memenuhi hak tergugat untuk mengajukan banding, kasasi, dan Peninjauan kembali, meskipun setiap upaya hukum selalu menguatkan putusan tingkat pertama.

Efektivitas dalam pelaksanaan pembagian harta milik bersama setelah terjadina perceraian tersebut disebutkan oleh Lawrence (Soerjono, 2015) bahwa hukum tersebut akan berlaku secara efektif didasarkan pada substansi hukum yang dimilikinya, termasuk didalamnya legal standing yang diperoleh penggugat karena adanya kerugian secara finansial dan tertentu pada penggugugat sebagai akibat ketidaktaatan hukum pihak tergugat. pelaksanaan putusan pembaguan harta milik Bersama setelah terjadinya perceraian tersebut terlaksana sesuai dengan ketentuan prosedur pada perintah ekseskusi harta yang terjadi berselang dua tahun dari waktu persidangan perceraian. 


\subsection{Faktor-faktor yang mempengaruhi Efektivitas Pembagian Harta Bersama Terhadap Perceraian pada Putusan nomor 79/PDT.G/2017/PA. SGM yang dipengaruhi factor sosiologi dan psikologi}

a. Faktor Sosiologi

Suatu efektivitas diukur didasarkan pada hal-hal yang mempengaruhi penerapannya baik itu kegagalan maupun keberhasilan yang menjadi acuan pencapaian yang telah direncanakan. berdasarkan pada teori sociological jurisprudence (Sajipto Rahadjo, 2015), maka norma efektivitas yang ditetapkan berdasarkan pada ukuran kepatuhan masyarakat terhadap hukum, tak terkecuali orang yang menegakkan hukum itu sendiri. Pada putusan Pengadilan Agama Sungguminasa nomor 79/PDT.G/2017/PA. SGM menunjukkan adanya kesempatan yang diberikan kepada pihak tergugat yang terus memberikan peluang mengajukan keberatan selanjutnya membuat faktor hukum tersebut dapat dinilai kurang efektif. Pengaruh efektivitas hukum yang diterapkan dalam pembagian harta Bersama yang tidak terlaksana secara real kemudian menjadi salah satu pembentuk kepercayaan yang dimiliki masyarakat dalam kehidupan sosial mereka.

b. Factor psikologi

Efektivitas penerapan hukum juga dapat dipengaruhi oleh ketidakadilan ini sangat berkaitan dengan sudut pandang suami selaku penanggungjawab keluarga terhadap istri selaku ibu rumah tangga dalam memberikan bagian dari Harta milik Bersama karena budaya. Budaya serta ideologi merupakan hal yang diatur oleh manusia. budaya tersebut diatur dan diwariskan secara turun temurun. Koentjaraningrat mengatakan nilai budaya adalah faktor mental yang menentukan perbuatan seseorang atau masyarakat.

Perilaku tergugat terhadap putusan pembagian harta milik Bersama yang tidak menunjukkan itikad baik termasuk pada kategori teroi sosial cognitive of self regulation, dimana teori tersebut mengkaji terkait proses yang mendasari seseorang menentukan kehidupannya sendiri yang berlandaskan pada aaltruisme dan moral yang dimiliki yang tercermin dari perilaku. Teori ini lebih berfokus pada aktivitas antara tersebut dan lingkungannya.

Adanya factor yang menghambat dalam penyelesaian peradilan berupa upaya hukum yakni banding sampai pada kasasi dipengaruhi karena di dalam prosesnya pengadilan menemui banyak perkara, sistem administrasi yang kurang lengkap, terlalu rumit sebuah kasus, adanay komunikasi yang kurang baik terhadap lembaga pengadilan, sarana dan prasarana yang kurang memadai, serta kewajiban sampingan para hakim yang cukup menambah sulit penegakan hukum. Meskipun terdapat kendala dalam proses penyelesaian perkara, namun sebenarnya kendala tersebut juga datang karena karakter dari tergugat yang tidak taat hukum, sehingga memeprlambat proses pembagian harta milik Bersama setelah adanya putusan secara sah dari pengadilan.

Terwujudnya efektivtias putusan nomor 79/PDT.G/2017/PA. SGM yang tidak terlaksana Ketika penetapan putusan diebrikan secara langsung memberikan status hukum kepada penggugat yang merupakan pihak yang tidak mendapatkan haknya dan merasa dirugikan. Dimana legal standing yang diperoleh penggugat dilandasi oleh beberapa hal bahwa:

a. Pemohon adalah pihak yang menganggap hak dan/atau kewenangan konstitusionalnya dirugikan oleh berlakunya Undang-Undang. Pemohon yang merupakan seorang perempuan yang tidak mendapatkan haknya disebabkan ketidaktaatan hukum terhadap putusan pengadilan terkait harta milik Bersama yang telah diputuskan terulur-ulur dikarenakan perlawanan hukum yang di lakukan pihak tergugat yang merupakan mantan suami penggugat yang secara nyata enggan memberikan bagian yang menjadi hak mantan istri.

b. Kerugian yang dialami oleh pihak pengugat karena upaya hukum yang ditempuh pihak tergugat meliputi pada kerugian finansial dan juga secara spikis. Dimana penggugat tidak mendapatkan haknya sebagaimana yang tertera dalam putusan. Panjangnya waktu untuk mendapatkan hak penggugat sehingga secara finansial harta Bersama yang sdah seharusnya dapat dikelola dan memberikan hasil harus tertunda. Selain itu untuk kerugian secara spikis disebabkan kepastian hukum yang tidak jelas terkait kapan penggugat dapat menerima haknya yang terhitung sudah sejak 2017 mengajukan gugatan, namun baru terkabul setelah 2019.

c. Adanya hubungan sebab akibat membuat penggugat memiliki legal standing. Karena adanya perceraian sehingga terjadilah perkara pembagian harta milik Bersama dan perceraia tersebut menimbulkan konflik antara dua orang yang telahbercerai. Dimana pihak tergugat tidak mau memberikan apa yang menjadi hak dari penggugat, sehingga menyebabkan penggugat mengajukan tuntutan atas haknya kepada tergugat.

d. Pemberian legal standing kepada penggugat karena terjadinya konfflik yang merugikan penggugat. Pemberian legal standing diharapkan dapat mencegah terjadinya Kembali kerugian terhadap penggugat yang disebabkan karena adanya itikad tidak baik tergugat memenuhi putusan nomor 79/PDT.G/2017/PA. SGM untuk membagi harta milik Bersama $1 / 2$ bagian untuk masing-masing penggugat dan tergugat.

Adapun peran aparat yaitu majelis hakim telah mengupayakan perdamaian antara keduanya dengan mediasi terhadap kedua pihak berperkara telah dilakukan mediasi oleh mediator, sedangkan apparat kepolisian sebagai keamanan dalam proses eksekusi barang telah dilaksanakan dan ditaati sebgaimana mestinya dan hal tersebut menunjukkan kefektivan penerapan putusan Pengadilan Agama Sungguminasa dengan Nomor 79/Pdt.G/2017/PA.Sgm.

Selanjutnya putusan nomor 79/PDT.G/2017/PA.SGM tentang harta Bersama yang diputuskan ditinau dari aspek sosiologi menurut teori sociological jurisprudence, maka efektivitas norma ditentukan oleh taraf kepatuhan masyarakat terhadap hukum, termasuk para penegak hukumnya. Dalam hal ini ketidakpatuhan tergugat merupakan factor keberhasilan putusandidtetapkan. Namun karena adanya upaya hukum dari tergugat maka kefektifan putusan baru dapat di wujudkan setelah berselang dua tahun dari gugatan pemohon.

Sedangkan pada aspek psikologi menunjukkan adanya ketidakadilan pada pembagian harta Bersama karena perspektif suami dan karena budaya. Dimana suami menggangap dirinyalah yang paling berhak membagi dan 
mendapatkan harga dengan jumlah yang lebih banyak sebagai kepala keluarga dalam pernikahan, sedangkan pada budaya yang mengacu pada keyakinan dimana Tuhan telah memberikan penetapan terkait perbedaan anatara laki-laki dan perempuan, yang selanjutnya membuat perbedaan dalam perlakuan manusia yang telah diatur didasarkan pada perbedaan, sehingga pada pembagian harta Bersama menjadi tidak efektif dalam penerapannya menurut putusan yang ditetapkan.

\section{KESIMPULAN DAN SARAN}

Hasil penelitian dan pembahasan dapat disimpulkan bahwa pembagian harta bersama dianggap berlaku efektif apabila di tinjau dan didukung dari dua hal yaitu legal standing dan peran aparat hukum serta pemerintah, Legal standing dapat dimiliki oleh seorang yang merasa dirugikan dan tidak mendapatkan haknya.serta dapat memberikan kejelasan hukum kepada pemohon dengan bantuan majelis hakim mengupayakan perdamaian melalui mediasi terhadap kedua belah pihak berperkara oleh seorang Mediator yang ditunjuk, sedangkan aparat kepolisian dan pemerintah harus lebih berperan aktif sebagai pengawal keamanan sampai proses eksekusi telah dilaksanakan dengan sempurna dan ditaati sebagaimana mestinya. Selanjutnya dalam menunjang efektivitas putusan terdapat dua factor yaitu faktor sosiologi dan faktor psikologi . Faktor sosiologi yakni terkait pada ukuran kepatuhan masyarakat terhadap hukum. Faktor psikologi yakni nilai budaya atau mental seseorang yang menunjukkan ketidak patuhan tergugat terhadap hukum sehingga sering mengancam, dan memukul, Penggugat, hingga semua upaya hukum telah dilakukan hingga berselang dua tahun lebih baru putusan tersebut berkekuatan hukum tetap baru dapat dimohonkan eksekusi oleh Penggugat. Adapun saran yang diajukan yakni sebaiknya Sita Jaminan (conservatoir beslag) yang diletakkan oleh Jurusita Pengadilan Agama tetap dianggap sah dan berharga sampai pada tahap ekseskusi dilaksanakan secara sempurna dan sebaiknya ada aturan / sanksi pidana yang berlaku terhadap pihak yang tidak melaksanakan putusan Hakim tentang pembagian harta bersama tersebut.

\section{DAFTAR PUSTAKA}

Achmad Ali. (2015). Menguak Tabir Hukum (Suatu Kajian Filosofis dan. Sosiologis). Chandra Pratama.

Ahmadi, A. (2015). Sosiologi Pendidikan. Andi.

Bimo Walgito. (2015). Psikologi Sosial Suatu Pengantar. Penerbit Rineka Cipta.

Hazairin. (2015). Tinjauan Mengenai Undang-Undang Perkawinan Nomor 1 Tahun 1974. TIntamas.

Mahadi. (2015). Perjanjian Perkawinan: Konsep Disertasi Henry Lie A Weng. Perpustakaan USU.

Samin, S. (2016). Fikih II. Alauddin Press.

Soerjono Soekanto. (2015). Faktor-faktor Yang Mempengaruhi Penegakan Hukum. CV. Rajawali Press.

Soerjono Soekanto dan Abdullah Mustafa. (2015). Sosiologi Hukum dalam Masyarakat. CV. Rajawali Press.

Sri Hariati \& Musakir Salat. (2015). Ketidakadilan Pembagian Harta Gono Gini Pada Kasus Perceraian. Kajian Hukum Dan Keadilan, 3, 448-463.

Sukdikno Mertokusumo. (2016). Penemuan Hukum Sebuah Pengantar. Liberty.

Wijayanti, W. (2015). Kedudukan Isteri Dalam Pembagian
Harta Bersama Akibat Putusnya Perkawinan Karena Perceraian Terkait Kerahasiaan Bank. Konstitusi, 10, Nomor, 723. 